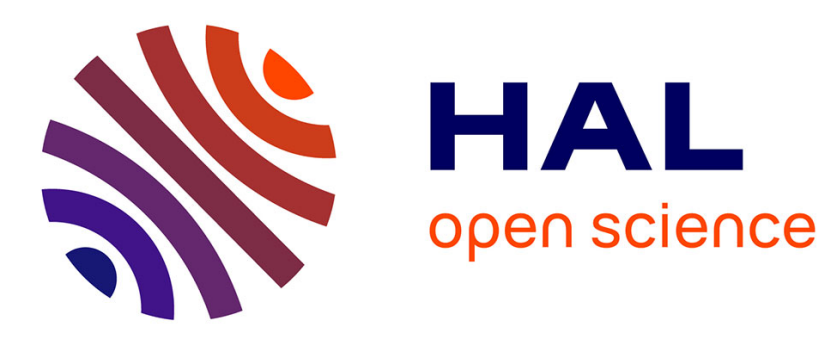

\title{
Viral and antibody HEV prevalence in swine at slaughterhouse in Italy
}

Ilaria Di Bartolo, Eleonora Ponterio, Laura Castellini, Fabio Ostanello, Franco Maria Ruggeri

\section{- To cite this version:}

Ilaria Di Bartolo, Eleonora Ponterio, Laura Castellini, Fabio Ostanello, Franco Maria Ruggeri. Viral and antibody HEV prevalence in swine at slaughterhouse in Italy. Veterinary Microbiology, 2011, 149 (3-4), pp.330. 10.1016/j.vetmic.2010.12.007 . hal-00683504

\section{HAL Id: hal-00683504 https://hal.science/hal-00683504}

Submitted on 29 Mar 2012

HAL is a multi-disciplinary open access archive for the deposit and dissemination of scientific research documents, whether they are published or not. The documents may come from teaching and research institutions in France or abroad, or from public or private research centers.
L'archive ouverte pluridisciplinaire HAL, est destinée au dépôt et à la diffusion de documents scientifiques de niveau recherche, publiés ou non, émanant des établissements d'enseignement et de recherche français ou étrangers, des laboratoires publics ou privés. 


\section{Accepted Manuscript}

Title: Viral and antibody HEV prevalence in swine at slaughterhouse in Italy

Authors: Ilaria Di Bartolo, Eleonora Ponterio, Laura

Castellini, Fabio Ostanello, Franco Maria Ruggeri

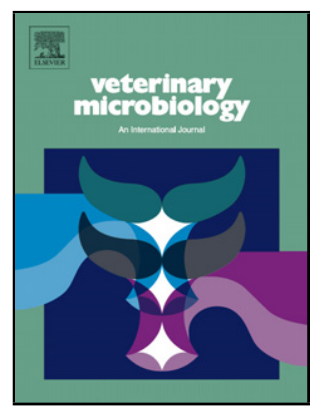

PII: $\quad$ S0378-1135(10)00580-8

DOI: $\quad$ doi:10.1016/j.vetmic.2010.12.007

Reference: $\quad$ VETMIC 5119

To appear in: $\quad$ VETMIC

Received date: $\quad 21-7-2010$

Revised date: 6-12-2010

Accepted date: $\quad$ 7-12-2010

Please cite this article as: Di Bartolo, I., Ponterio, E., Castellini, L., Ostanello, F., Ruggeri, F.M., Viral and antibody HEV prevalence in swine at slaughterhouse in Italy, Veterinary Microbiology (2010), doi:10.1016/j.vetmic.2010.12.007

This is a PDF file of an unedited manuscript that has been accepted for publication. As a service to our customers we are providing this early version of the manuscript. The manuscript will undergo copyediting, typesetting, and review of the resulting proof before it is published in its final form. Please note that during the production process errors may be discovered which could affect the content, and all legal disclaimers that apply to the journal pertain. 
3 Ilaria Di Bartolo ${ }^{\mathrm{a}, *}$, Eleonora Ponterio ${ }^{\mathrm{a}}$, Laura Castellini ${ }^{\mathrm{b}}$, Fabio Ostanello $^{\mathrm{c}}$, Franco Maria Ruggeri $^{\mathrm{a}}$

4 a D epartment of Veterinary Public H ealth and F ood Safety, I stituto Superiore di Sanità, Rome, 5 Italy.

$6 \quad{ }^{b}$ D epartment of Internal M edicine, Policlinico U niversitario "A. G emelli", Rome, Italy.

7 'D epartment of Veterinary Public Health and Animal Pathology, U niversity of Bologna, Italy. 8

9 * Corresponding author: Ilaria Di Bartolo

10 Istituto Superiore di Sanità

11 Department of Veterinary Public Health and Food Safety

12 Viale Regina Elena 299

1300161 Rome, Italy

14 Tel.: +3906 4990 2787; fax: +39064938 7077 .

15 E-mail address: ilaria.dibartolo@iss.it (I. Di Bartolo).

16 


\section{Abstract:}

2 Hepatitis E is an acute disease of humans caused by a small RNA virus, Hepatitis E virus (HEV). In

3 recent years, an increasing number of autochthonous human infections have been reported in

4 industrialized countries. Genotype 3 is the main HEV type circulating in swine, and is also reported

5 in sporadic cases of hepatitis E in humans worldwide. To date one serotype has been described. We

6 have conducted a survey to detect antibodies against HEV in 48 swine at a slaughterhouse in

7 Northern Italy, using ELISA test. Mean seroprevalence in the studied animal group was 87.\%. Bile,

8 liver and feces from the 48 animals were also collected, and HEV RNA was detected by nested

9 reverse transcription-polymerase chain reaction, amplifying a fragment of the ORF2. HEV genome

10 was most frequently detected in bile samples (51.1\%), followed by feces (33.3\%) and liver (20.8\%).

11 Thirty-one out of 48 studied pigs $(64.6 \%)$ were positive for HEV RNA in at least one sample.

12 Overall, HEV RNA was found at a statistically higher rate in the 3-4 month-old than in 9-10 month-

13 old animals (95.0\% vs. $42.9 \%)$. Genetic characterization of swine strains identified was performed

14 by sequencing and database alignment. Phylogenetic analysis on the nucleotide sequences from 16

15 positive PCR products indicated that all strains belonged to genotype 3, clustering in two branches 16 subtypes g3c and g3f.

17

18 Keywords: Hepatitis E Virus; Genotype 3, swine;-ELISA. 


\section{1. Introduction}

2 Hepatitis $\mathrm{E}$ is an important cause of enterically transmitted self-limiting non-A, non-B hepatitis in 3 humans (Purcell and Emerson, 2001). The etiological agent is a small non-enveloped positive sense 4 single-stranded RNA virus, the Hepatitis E virus (HEV), recently classified in the new Hepevirus 5 genus in the proposed family Hepeviridae (Emerson et al., 2004). The genome of HEV is 6 approximately $7.5 \mathrm{~kb}$, and contains three open reading frames (ORFs) and short 5' and 3' 7 untranslated regions. ORF1 encodes non-structural proteins including an RNA-dependent RNA 8 polymerase, whereas ORF2 encodes the glycoprotein of the viral capsid, and ORF3 a small protein 9 of unknown function (Panda et al., 2007). Although one serotype is actually recognized, HEV is classified in four different genotypes based on the nucleotide sequence, and 24 subtypes (Lu et al., 11 2006), which show different geographical distributions.

Particularly, genotype 1 and 2 have been described in Asia, Africa and Mexico, and include 13 primarily human strains (Schlauder and Mushahwar, 2001) that can be further divided into five (a14 e) and two ( $a$ and b) subtypes, respectively. Conversely, genotype 3 and 4 strains circulate in Asian, 15 American and European developed countries, and have been detected in humans, pigs, and other animal species. Genotype 3 and 4 can be divided into ten $(\mathrm{a}-\mathrm{j})$ and seven $(\mathrm{a}-\mathrm{g})$ subtypes (Lu et al., 2006; Vasickova et al., 2009). A fifth HEV genotype has been suggested to infect rabbits (Zhao et al., 2009), showing approximately $75 \%$ nucleotide divergence from established HEV types. Hepatitis $\mathrm{E}$ is considered to be endemic in several developing countries, where it occurs as outbreaks mainly transmitted via fecally contaminated drinking water (Emerson and Purcell, 2003).

21 In industrialized countries, HEV infection is sporadic and is often reported in patients with history 22 of travelling in endemic areas (Péron et al., 2006). However, in the last decade an increasing number of sporadic human HEV cases without history of travelling have been reported in Japan,

24 USA and several European countries, including Italy (Zanetti et al., 1999; Buti et al., 2004; Borgen et al., 2008; Dalton et al., 2008; Mansuy et al., 2009). 
The overall mortality rate associated with Hepatitis E is generally low $(<1 \%)$, except for

2 pregnant women, who may exhibit mortality rates up to 28\% (Purcell and Emerson 2001;

3 Mushawar, 2008). Despite the low number of cases diagnosed in developed countries,

4 seroprevalence of HEV in humans can vary from 1\% to 16\% (Buti et al., 2006; Mansuy et al.,

5 2008). Several studies have shown that the pig farmers, swine veterinarians and other swine

6 workers, have an increased risk of HEV infection (Meng et al., 2002; Vulcano et al., 2007;

7 Bouwknegt et al., 2008). Moreover, recent investigations have shown that seropositive animals are

8 present in up to $97 \%$ of the pig herds (Rutjes et al., 2007; Seminati et al., 2008). These evidences,

9 together with the detection of anti-HEV antibodies in animals such as rodents (Favorov et al.,

10 2000), pigs, cows and goats (Wang et al., 2002) suggest that hepatitis E virus may also have a

11 zoonotic transmission and that animals can act as a reservoir.

12 The first animal strain of HEV was identified in a pig in the United States in 1997, and was

13 shown to be closely related to human HEV (Meng et al., 1997). Several data, involving sporadic

14 and clustered human cases of hepatitis E, support transmission of HEV to humans from swine, wild

15 boar and deer, in some cases related to consumption of raw meat. The genomic sequences of the

16 viruses identified in food or animals in these cases were in fact closely related to each other

17 (Matsuda et al., 2003; Tei et al., 2003; Yazaki et al., 2003; Li et al., 2005). Most importantly, in

18 Japan and in the US, $2 \%$ and $11 \%$ of commercial pig livers sold in grocery stores were positive for

19 swine HEV RNA (Yazaki et al., 2003; Feagins et al., 2007). In Italy, the first autochthonous human

20 case of hepatitis E was reported (Zanetti et al., 1999) in 1997, and the virus identified belonged to

21 genotype 3. A limited number of studies conducted on pigs in Northern Italy (Caprioli et al., 2007;

22 Di Bartolo et al., 2008) indicate that swine HEV circulates largely within pig herds in the country,

23 although consistent data on possible different prevalence of viral infection in pigs by age,

24 particularly among animals entering the pork food chain, are still unavailable.

This study was aimed to assess if HEV is present in swine at the slaughterhouse, and the

26 genetic correlation between viruses detected in Italian pigs with other strains circulating in Europe. 
1 Anti-HEV serum antibody was determined by a commercial ELISA test adapted to detect swine

2 antibodies. Moreover, HEV RNA was determined in bile, liver and feces samples, and genetic

3 characterization of identified HEV swine strains was performed against existing sequences of

4 human and swine origin.

\section{2. Materials and methods}

$6 \quad$ 2.1. Pigs and samples

7 Between November-December 2008, 46 sera, 48 livers, 48 stools and 45 bile samples were

8 collected in a slaughterhouse in Northern Italy from 48 clinically healthy pigs, belonging to five

9 different farms from the surrounding area. Twenty-eight animals were 9-10 month-old (160-170 kg live body weight, usual age for slaughtering in Italy) and twenty were 3 month-old.

From each animal a bile sample was withdrawn with a sterile syringe (used once and then discarded) through the gall-bladder wall, and a sample of gross intestine content was collected after cutting the bowel with a sterile blade. Samples were stored at $-80^{\circ} \mathrm{C}$ until processing. Fecal and bile samples were suspended in $10 \%$ diethyl pyrocarbonate (DEPC) water, and were stored at $-80^{\circ} \mathrm{C}$ until analyzed. Pig livers were collected and stored immediately at $-80^{\circ} \mathrm{C}$. Serum samples were obtained from intracardiac clot and stored at $-20^{\circ} \mathrm{C}$.

A $200 \mathrm{mg}$ sample of each pig liver was homogenized using a Tissue Lyser (Qiagen, Hilden, Germany). The obtained homogenate (around $0.75 \mathrm{ml}$ ) was centrifuged for 3 min at 13,000 rpm twice, and the supernatant was collected and immediately subjected to RNA extraction using the RNeasy Mini kit (Qiagen, Hilden, Germany), and eluted in $60 \mu 1$ DEPC water, according to the manufacturer's instructions.

One-hundred seventy microliters of $10 \%(\mathrm{~W} / \mathrm{vol})$ fecal and 10\% (vol/vol) bile suspensions were used for viral RNA extraction, using the RNeasy Mini kit (Qiagen, Hilden, Germany). 
1 USA), and two degenerate primer sets targeting the ORF2 region encoding for the capsid protein.

2 External primer forward HEVORF2con-s1-5' GACAGAATTRATTTCGTCGGCTGG-3' and

5

GTYGTCTCRGCCAATGGCGAGC-3' reverse HEVORF2con-a1—5' CTTGTTCRTGYTGGTTRTCATAATC-3' were used for RT-PCR,

GTTCRTGYTGGTTRTCATAATCCTG-3' inner primers were used, yielding a final product of 145 bp (Erker et al., 1999).

Briefly, $0.4 \mu \mathrm{M}$ of primers HEVORF2con-s1 and HEVORF2con-A1 and $3 \mu \mathrm{l}$ of extracted RNA were used in RT-PCR in a final volume of $15 \mu$. Reverse-transcription and PCR were performed under following conditions: RT cycle at $45^{\circ} \mathrm{C}$ for $30 \mathrm{~min}$, denaturation at $94^{\circ} \mathrm{C}$ for 2 min, and 40 cycles at $94^{\circ} \mathrm{C}$ for $45 \mathrm{~s}, 49^{\circ} \mathrm{C}$ for $45 \mathrm{~s}$, and $72^{\circ} \mathrm{C}$ for $1 \mathrm{~min}$, followed by a final elongation step of $72^{\circ} \mathrm{C}$ for $7 \mathrm{~min}$. For the second round nested PCR, the inner oligos HEVORF2con-s2 and HEVORF2con-a2 $(0.3 \mu \mathrm{M})$ were used, with $2 \mu$ of DNA template obtained from the first RT-PCR or $2 \mu \mathrm{l}$ a ten-fold dilution (amount of template corresponding to $10 \%$ of the final volume), using AmpliTaq DNA polymerase (Applied Biosystems, ABI, Foster City, CA, USA) according to the manufacturer's instruction. The PCR was performed as follows: 1 cycle at $94^{\circ} \mathrm{C}$ for $10 \mathrm{~min}$, followed by 40 cycles at $94^{\circ} \mathrm{C}$ for $45 \mathrm{~s}, 50^{\circ} \mathrm{C}$ for $45 \mathrm{~s}$, and $72^{\circ} \mathrm{C}$ for $1 \mathrm{~min}$, and a final elongation step of $72^{\circ} \mathrm{C}$ for $7 \mathrm{~min}$.

To obtain a longer DNA fragment for sequencing, samples positive to the first protocol described above were also analyzed using a second nested RT-PCR procedure with primer pairs 3156-3157 (first run) and 3158-3159 (nested-PCR) (Huang et al., 2002) amplifying a 320 bp region in ORF2. The amount of RNA, DNA and the parameters for the second RT-PCR protocol were similar to the first one, except that primers 3156-3157 (first run) and 3158-3159 were used.

Negative (DEPC water samples) and positive (a collection swine bile sample, previously confirmed to be positive for HEV; Martelli et al., 2008) samples were included as controls in each step: RNA extraction, first and second PCRs. All samples resulting negative were re-tested in 
1 nested-PCR using a ten-fold dilution of the first PCR. Moreover, to evaluate if negative results were

2 due to inhibition, RNA resulted negative to PCR analysis were spiked with a positive control HEV

3 RNA and re-tested. All spiked RNA samples resulted positive, confirming the absence of inhibitors. Amplified products were stained with ethidium bromide in a $\%$ agarose gel. To abate risks of cross-contamination, each phase of diagnostic routine (from sample preparation throughout nested PCR) was completed in separate rooms, inside biohazard cabinets or PCR hoods, and using

7 dedicated equipment, pipettes and disposables.

\subsection{Sequencing and phylogenetic analysis}

9 Positive DNA PCR products, obtained with the second nested-PCR protocol (see above), were excised from agarose gels and purified using the Nucleospin Extract II (Macherey-Nagel Gmbh \&

11 Co., Düren, Germany) following manufacturer's instructions. Unfortunately, it was not possible to sequence all samples due to the low amount of DNA. Sequence reactions were performed by

13 Macrogen Inc. (Seoul, Korea). Sequences obtained (Acc. no. HM769970; HM769971; HM769972;

14 HM769973; HM769974; HM769975; HM769976; HM769977; HM769978; HM769979;

15 HM769982; HM769980; HM769981; HM769983) were compared with those of HEV available in

16 NCBI GenBank (http://www.ncbi.nlm.nih.gov). Alignments were performed using DNASIS Max

17 software (Hitachi Software Engineering Company, Alameda, CA, USA). Phylogenetic analyses

18 were carried out with the Bionumerics software packages (Applied Maths, Kortrijk, Belgium), and

19 the dendrogram was obtained with the UPGMA method.

20 2.4. ELISA commercial kit

21 Swine sera (diluted 1:20) were tested by the commercial ELISA BioChain kit (Hayward, CA, 22 USA), intended for detection of anti-HEV IgG antibodies in human sera, with the following 23 modifications. For the analysis of porcine samples, the secondary antibody was replaced with a 24 Horseradish peroxidase-labeled mouse anti-swine IgG antibody (SIGMA, St. Louis, MO, USA), 25 diluted 1:10,000. The ELISA cut-off was established following this formula: Cut off Value (COV) $26=0.1+$ the mean OD of negative controls. Test sera were considered as positive if OD450 was 
1 greater than the COV value, as indicated by manufacturer. Three sera from SPF pigs were used as

2 negative controls, and a serum from an experimentally infected swine (kindly provided by Dr.

3 Nicole Pavio, ANSES-ENVA-INRA, Maisons-Alfort, France; Rose et al., 2010) was used as

4 positive control in all experiments.

$5 \quad 2.5$. Statistical analysis

6 To identify a possible correlation between the HEV prevalence and anti-HEV seroprevalence and

7 the age of animals, swine were subdivided in two categories (young animals: 3-4 months of age and

8 adult animals: 9-10 months of age). All statistical analyses were performed using the software SPSS

$9 \quad 12.0 .0$ (SPSS Inc., Chicago, IL, USA).

\section{3. Results}

11 3.1. HEV detection by RT-PCR

12 HEV RNA was detected in at least one sample collected from 31 out of 48 pigs examined (64.6\%),

13 based on results obtained with the first testing nested RT-PCR protocol amplifying a $145 \mathrm{nt}$ stretch

14 of the ORF2 (Erker et al., 1999). The results of HEV detection in the feces, bile and liver are

15 summarized in Table 1, with respect to the age of swine. Bile was the type of sample most

16 frequently found positive for HEV RNA (23/45), followed by feces (16/48) and livers (10/48). HEV

17 RNA was detected in both pigs of 3-4 (19/20) and 9-10 (12/28) months of age, although to different

18 rates. In younger swine, the HEV RNA prevalence in bile or feces was significantly higher than in

19 fattening pigs $\left(\chi^{2}=3.94, p=0.047 ; \chi^{2}=15.47, p=0.001\right)$. Conversely, no statistically significant

20 differences $(\mathrm{p}>0.05)$ were observed in the HEV prevalence in liver samples between age classes.

21 Considering the detection of HEV RNA in at least one sample, a significantly higher HEV

22 prevalence $\left(\chi^{2}=13.87 ; p=0.001\right)$ was altogether observed in swine of 3-4 months, with 19 positives

23 out of 20 tested (95.0\%), than in adult animals (9-10 months), in which the prevalence was $42.9 \%$

24 (12 positives out of 28 tested). 
Moreover, 17 animals resulted positive for more than one sample (Table 1). In one animal,

2 HEV RNA was detected in all three specimens tested, whereas nine pigs were positive for bile and

3 feces, five for bile and liver, and two for liver and feces.

4 To obtain a longer stretch of DNA to be analyzed by sequencing, a subset of 33 samples (14 bile, 12

5 feces and 7 liver), positive at the first analysis, were further analyzed using a second nested-RT-

6 PCR protocol (Huang et al., 2002), that amplifies a 320 nt ORF2 fragment. In 18 cases out of 33

7 samples, positivity was confirmed by both PCR tests.

\section{$8 \quad 3.2$. Seroprevalence of swine HEV antibodies}

9 Forty out of 46 swine sera tested ( $87 \%$ ) resulted positive by a commercial ELISA test adapted to 10 detect swine IgG antibody. Swine polyclonal sera were used as positive and negative controls (see 11 Materials and Methods). No statistically significant differences $(p>0.05)$ in the HEV 12 seroprevalence were detected between age classes. The seroprevalence was slightly higher in swine 13 of 9-10 months (25 positive/27 total; 92.6\%), than in animals of 3-4 months, in which the 14 seroprevalence was $78.9 \%$ (15/19). The proportion of HEV RNA positive bile, feces and liver 15 samples did not differ significantly $(\mathrm{p}>0.05)$ between seronegative and seropositive pigs.

Twenty-five of the $40(62.5 \%)$ seropositive pigs were also positive for HEV genome in bile,

17 liver and/or feces, whereas fifteen (37.5\%) were negative for the presence of viral RNA in any 18 sample (Table 2).

Two out of $6(33.3 \%)$ seronegative animals were negative for the presence of viral RNA in all samples, whereas the remaining four (66.7\%) pigs were positive for HEV genome in their bile,

21 liver and/or feces (Table 2).

For two animals sera samples could not be collected and these were not included into this 23 comparison.

24 3.3. Sequencing and phylogenetic analysis

25 Partial sequences (320 nt ORF2 fragment) of the capsid protein gene were obtained from 14 
$1 \quad$ samples (5 from bile, 5 feces and 4 liver) and deposited into NCBI GenBank (Acc. no. HM769970;

2 HM769971; HM769972; HM769973; HM769974; HM769975; HM769976; HM769977;

3 HM769978; HM769979; HM769982; HM769980; HM769981; HM769983). HEV sequences were

4 obtained from both liver and bile samples in one case, and from bile and stools from three pigs. In

5 these cases, a nucleotide identity of $100 \%$ between the HEV sequences obtained from different

6 specimens of the same pig was found. Following sequencing and comparative analysis with all the 4

7 known genotypes of $\mathrm{HEV}$, all sequences were found to belong to genotype g3, as reported

8 previously for porcine and human HEV from Europe, and clustered in either subtype $\mathrm{c}$ or $\mathrm{f}$ (Figure

9 1). The two clusters, g3c and g3f, showed nucleotide identity of $79 \%$ one to each other. The $8 \mathrm{HEV}$

10 strains forming the g3c cluster showed $98.9-100 \%$ nucleotide identity one to each other (Acc. no.

11 HM769970; HM769971; HM769973; HM769979; HM769980; HM769981; HM769982;

12 HM769983). This branch shared 81.7-92\% nucleotide identity with other g3c HEV sequences

13 available in NCBI GenBank. With respect to other Italian swine HEV strains, the present g3c HEV

14 strains showed up to $100 \%$ nucleotide identity with strain HEVSwBO88IT/06 previously described

15 by Martelli et al. in 2010 (Acc. no. GU369940).

16 The second cluster, enclosing $6 \mathrm{HEV}$ sequences of genotype $3 \mathrm{f}$ shared $88.4 \%$ nucleotide

17 identity with other genotype $3 f$ strains sequences available in NCBI GenBank. This cluster

18 displayed an $80 \%$ nucleotide identity with earlier swine HEV strains described in Italy (Martelli et

19 al., 2010; Acc. no. GU178998-99). The present 3f HEV strains showed a nucleotide identity one to

20 each other ranging between 94\% and 100\% (Acc. no. HM769972; HM769974; HM769975;

21 HM769976; HM769977; HM769978). Seventeen additional sequences were obtained from 12 fecal

22 and 5 liver samples, using the $121 \mathrm{bp}$ fragments obtained with a different nested RT-PCR protocol

23 (Erker et al., 1999); also this sequence group confirmed that all HEV strains belonged to g3,

24 subtype c and f. Identity to swine HEV strains previously described in Italy was $88.5 \%$ (Acc. no.

25 EF682083) to 100\% (Di Bartolo et al., 2008; Acc. no. EF681107), for strains belonging to subtype

26 f. Strains belonging to subtype c shared $80.9 \%$ nucleotide identity with a swine HEV strain recently 
1 reported in Italy (Acc. no. GQ223721.1; Di Martino et al., 2010) (data not shown). Due to their

2 short length, the 121 bp DNA amplicons obtained by the con-a2/con-s2 nested-RT-PCR were not

3 included into comparative phylogenetic analysis.

4 4. Discussion

5 In the last decade, several cases of human hepatitis E potentially transmitted through swine-human

6 contact or related to consumption of raw meat from infected deer, pig or wild boar have been

7 reported (Matsuda et al., 2003; Tei et al., 2003; Yazaki et al., 2003; Li et al., 2005). Due to the lack

8 of conventional cell culture systems to isolate the virus, diagnosis relies on molecular detection of

9 genomic HEV RNA in clinical samples, or food or environmental matrices. Although sensitive,

10 molecular approaches are limited by the knowledge that HEV viremia and shedding have usually

11 short duration (Peralta et al., 2009; Kanai et al., 2010). Furthermore, in pigs HEV infection is

12 asymptomatic, making it impossible to target peak infection phases for optimal test sensitivity.

13 The present study was planned to assess the presence of HEV infection in pigs at

14 slaughterhouse, and it complements information from previous investigations conducted in Italy

15 showing extensive viral circulation in breeding farms. Also, it further confirms that despite some

16 differences in infection rates between ages, the farmed swine retains it susceptibility to HEV at any

17 age, and that a remarkable proportion of pigs shed virus even at the latest breeding stages when they

18 are transferred to slaughter, that in Italy normally involves also animals of 9 months of age and

19 more.

20 In fact, nested RT-PCR testing in this study revealed that $64.6 \%$ (31 out of 48 examined

21 pigs) were overall positive for the presence of HEV genome, although as many as 95\% (19 out of

22 20) of young pigs (3-4 months of age) resulted to be infected compared to $42.9 \%(12 / 28)$ of adults

23 (9-10 months of age). Similar findings have been recently reported in several European countries,

24 including Italy (Di Bartolo et al., 2008) where HEV positive animal were detected in all age groups

25 (Fernandez-Barredo et al., 2006; de Deus et al., 2007; Leblanc et al., 2007; McCreary et al., 2008;

26 Breum et al., 2010). The higher prevalence detected in younger animals compared to older animals 
1 is in line with the hypothesis that, as it occurs for other infectious diseases, young animals are more

2 susceptible also to HEV infection, due to loss of maternal immunity (Meng et al., 1997; Kanai et al.,

3 2010) or to an incomplete or short-lasting protective immunity, permitting continuous re-infection

4 (Fernandez-Barredo et al., 2006).

The novelty of the present study was the simultaneous detection of swine HEV genome in both tissues (liver), and excretions (bile and feces) of the same naturally infected pig. The results obtained showed that the bile was the most frequently positive sample where to detect the virus (23/45), followed by fecal samples (16/48) and livers (10/48).

Bile has been previously indicated as the sample where HEV can be detected more easily, for longer periods and more frequently than in liver, feces and serum (Halbur et al., 2001; de Deus et al., 2007). This is probably due to the fact that liver is the main site of virus replication, and although liver infection may be focal, thus reducing the chance of collecting positive tissue samples for diagnostics, viral progeny is in all cases accumulating in the bile (Williams et al., 2001; de Deus et al., 2007).

The higher prevalence $(64.6 \%)$ of genotype $3 \mathrm{HEV}$ infections detected in this study, compared to that observed among Italian pigs previously $(5.9 \%$, Caprioli et al., 2007; 42\%, Di Bartolo et al., 2008; 7.3\%, Di Martino et al., 2010; 29.9\%, Martelli et al., 2010) can be due at least in part to multiple types of samples tested from the same animal, increasing the sensitivity of HEV RNA detection. As described previously, the choice of the samples may in fact be crucial for successful molecular diagnosis (de Deus et al., 2007; Vasickova et al., 2009). Also the RNA detection method used could be crucial. In fact, our results confirm a different sensitivity of different methods, suggesting that the use of several RT-PCR protocols may increase sensitivity of HEV RNA detection (Vasickova et al., 2009). In our study, not all of the positive samples detected with a first protocol, amplifying a $120 \mathrm{nt}$ genome fragment, could be confirmed with a different method that amplifies a longer genome fragment (Huang et al., 2002) although this latter resulted useful for a more detailed comparison of HEV strain nucleotide sequences. 
As an aid to diagnostics and for epidemiological studies on HEV infection prevalence,

2 several immunologic tests have been developed for antibody detection in serum, but available diagnostic kits are intended for human use, and are based on HEV genotype 1 or 2 peptides. Although recent studies suggest that genotype 3 antigen derived from swine HEV may be a better candidate for testing HEV serology in pigs (Rose et al., 2010), only one serotype has been described for HEV ( $\mathrm{Lu}$ et al., 2006), and differences between ORF2 proteins of human and swine origins do not seem to be relevant (Arankalle et al., 2007). Commercial ELISA tests for humans can therefore be used for animal sera, provided a suitable secondary antibody specific for the animal immunoglobulin is used. With a similar approach, we have tested swine sera in the present study.

Not unexpectedly, presence of serum antibody directed at HEV involved overall a higher proportion of pigs, forty out of 46 swine sera tested (87\%), compared to detection of virus genome (64.6\%). The seroprevalence rate in 3-4 months old pigs was $78.9 \%$, reaching $92.6 \%$ in $9-10$ months old pigs. As described by others (de Deus et al., 2008; Seminati et al., 2008), seroprevalence increases with age, as a consequence of repeated contact with the virus. In our study, the 2 different age groups examined showed only a moderate difference in seropositivity, which increased up to $92.6 \%$ in the older animal group (9-10 months), indicating that pigs aged 3-4 months have already been largely exposed to the circulating virus sustaining high antibody prevalence within the herd.

The proportion of HEV RNA positive stools and livers did not differ markedly between pigs with presence or absence of anti-viral serum antibody. In fact, HEV seropositive and seronegative pigs had a positive PCR in $32.5 \%$ (13/40) and 33.3\% (2/6) of fecal samples, respectively. Bigger yet not statistically significant difference were found for liver and bile samples, which contained HEV RNA in $17.5 \%(7 / 40)$ vs. $50.0 \%(3 / 6)$ and in $51.4 \%(19 / 37)$ vs. $33.3 \%(2 / 6)$, respectively, for seropositive compared to seronegative pigs. The proportion of RNA positive bile samples in seronegative animals (33.3\%) was identical to that determined for stool (33.3\%)and-higher for liver (50\%). In line with the concept that replicating in the liver, before its release into the gut, HEV is accumulated in the gallbladder, where it may likely reach higher concentrations than in other 
1 matrices, a remarkably higher number of seropositive pigs exhibited presence of HEV RNA in the

2 bile (51.4\%). It is possible that these latter pigs were undergoing a more productive phase of HEV

3 infection in their liver at the time of sampling, consequently exhibiting an enhanced serum antibody

4 production and viral titer in the blood. This is however hard to demonstrate, as both molecular and

5 immunological methods for HEV may have a limited sensitivity, particularly in the pig, and because

6 presence of RNA does not necessarily correlate with the infectious titer of virus. Overall, when

7 applicable, bile testing for virus RNA may represent the most sensitive indication of productive 8 infection.

9 Four pigs proved HEV RNA-positive in the absence of measurable serum antibodies. HEV

10 RNA was detected in fecal samples from 2 of these animals, in bile from 2 animals and in liver

11 from 3. These samples were tested repeatedly and resulted consistently positive for HEV, and at

12 least in the 3 cases with HEV RNA in liver and/or bile, the antibody seronegativity is likely to

13 indicate a recent viral infection not yet resulted in a detectable immune response to HEV, although

14 a possible false negative result of serological test may not be ignored. In the remaining case, with

15 only positive HEV stools, these possibly reflect ingestion and transient intestinal presence of the

16 virus, without any further replication.

17 Another finding of this study is the observation that different HEV strains circulate among

18 Italian pigs, as provided by sequence analysis of a 320 nt ORF2 fragment. All strains detected

19 belonged to g3, which is the only genotype found thus far in Europe from either pigs or humans

20 with endemic hepatitis E (Mansuy et al., 2004; Ijaz et al., 2005; Dalton et al., 2007; Fogeda et al.,

21 2009; Norder et al., 2009; Brost et al., 2010). The ORF2 fragment sequences obtained clustered in

22 two main branches, corresponding to subtype $\mathrm{f}$ (6/14 cases tested) and c ( 8 cases). The two clusters,

$23 \mathrm{~g} 3 \mathrm{f}$ and g3c, showed nucleotide identity of $79 \%$ one to each other. Subtype $\mathrm{f}$ is the genotype most

24 commonly found in pigs and humans in European countries (Fogeda et al., 2009; Kaba et al., 2009;

25 Rutjes et al., 2009) including Italy; in our previous studies g3f HEV strains have been detected in

26 pigs and wild boars (Caprioli et al., 2007; Di Bartolo et al., 2008; Martelli et al., 2008; Martelli et 
1 al., 2010). More recently, spreading of g3c in European pigs has been reported (Rutjes et al., 2009)

2 including detection of this subtype in pigs in Italy (Di Martino et al., 2010; Martelli et al., 2010). In

3 Italy, the actual prevalence of hepatitis $\mathrm{E}$ in humans is not known, although an earliest human case

4 of autochthonous HEV was described in the remote 1999 (Zanetti et al., 1999). This HEV strain,

5 sequenced in a short stretch of the ORF2, was found to belong to genotype 3c, and comparison with

6 the same region of the swine strains reported in this study yields $83.9 \%$ nucleotide identity. We

7 have also shown that HEV sequences obtained from different types of specimen from a same

8 animal shared a nucleotide identity of $100 \%$, suggesting that a single HEV strain was replicating in

9 each animal infected, or was at least overgrowing other possible coinfecting strains.

The results obtained in this study are important for addressing risks for public health, since

11 HEV has been detected at high level (64.6\%) in apparently healthy animals at slaughterhouse, next

12 to entering the pork production chain and being commercialized. The risk of HEV transmission due

13 to consumption of raw meat and due to contact with pigs has already been highlighted in other

14 countries, as HEV RNA was detected in pig liver at grocery stores in Japan, The Netherlands and

15 USA (Yazaki et al., 2003; Bouwknegt et al., 2007; Feagins et al., 2007). Raw liver is not widely

16 consumed, although eating of fresh liver sausage (Figatellu) has recently been associated with an

17 upsurge of hepatitis E cases in France (Colson et al., 2010). Limited information is available on

18 HEV presence in pig muscle, where virus detection is made harder than in liver by lower virus

19 concentration (Williams et al., 2001; Bouwknegt et al., 2009). Unfortunately, in this study muscle

20 was not available. Since presence of HEV in muscle can be expected to be much lower than in liver,

21 this issue should better be resolved in studies involving high numbers of animals. In addition, HEV

22 RNA was detected in slaughterhouse workers in UK and Spain (Dalton et al., 2007; Galiana et al.,

23 2008), suggesting that HEV transmission from pigs to humans during slaughtering may also occur.

24 Also in Italy, a recent serological study has shown that contact with pigs may increase the risk of

25 infection for workers (Vulcano et al., 2007). 


\section{Acknowledgements}

2 This study was partially supported by grants from the Ministry of Health, Italy:

3 "Preparedness and response to emerging zoonoses and exotic viral infection through an integrated

4 medical and veterinary approach", Strategic Program 2007; and "Sviluppo di tecniche molecolari

5 idonee all'identificazione di virus a trasmissione gastrointestinale con potenziale o accertata

6 trasmissione zoonotica - Calicivirus enterici, Epatite E e Rotavirus - nella filiera di produzione del

7 suino", Ricerca Finalizzata 2006 - MSRF0106 Programma straordinario. This study was partially

8 supported by the European MEDVETNET network's Work Package 31 ( $\mathrm{n}^{\circ}$.-CT-2004-506122).

9 


\section{1}

2

3

4

5

6

7

\section{References:}

Arankalle, V.A., Lole, K.S., Deshmukh, T.M., Chobe, L.P., Ganghe, S.S., 2007. Evaluation of human (genotype 1) and swine (genotype 4)-ORF2-based ELISAs for anti-HEV IgM and IgG detection in an endemic country and search for type 4 human HEV infections. J. Viral Hepat. 14, 435-445.

Borgen, K., Herremans, T., Duizer, E., Vennema, H., Rutjes, S., Bosman, A., de Roda Husman, A.M., Koopmans, M., 2008. Non-travel related hepatitis E virus genotype 3 infections in the Netherlands; a case series 2004-2006. BMC Infect. Dis. 8, 61.

Bouwknegt, M., Lodder-Verschoor, F., van der Poel, W.H., Rutjes, S.A., de Roda Husman, A.M., 2007. Hepatitis E virus RNA in commercial porcine livers in The Netherlands. J. Food Prot. $70,2889-2895$.

Bouwknegt, M., Engel, B., Herremans, M.M., Widdowson, M.A., Worm, H.C., Koopmans, M.P., Frankena, K., de Roda Husman, A.M., De Jong, M.C., Van Der Poel, W.H., 2008. Bayesian estimation of hepatitis E virus seroprevalence for populations with different exposure levels to swine in The Netherlands. Epidemiol. Infect. 136, 567-576.

Bouwknegt, M., Rutjes, S.A., Reusken, C.B., Stockhofe-Zurwieden, N., Frankena, K., de Jong, M.C., de Roda Husman, A.M., Poel, W.H., 2009. The course of hepatitis E virus infection in pigs after contact-infection and intravenous inoculation. BMC Vet. Res. 4, 5-7.

Breum, S.O., Hjulsager, C.K., de Deus, N., Segalés, J., Larsen, L.E., 2010. Hepatitis E virus is highly prevalent in the Danish pig population. Vet. Microbiol. 146, 144-149.

Brost, S., Wenzel, J.J., Ganten, T.M., Filser, M., Flechtenmacher, C., Boehm, S., Astani, A., Jilg, W., Zeier, M., Schnitzler, P., 2010. Sporadic cases of acute autochthonous hepatitis E virus infection in Southwest Germany. J. Clin. Virol. 47, 89-92.

Buti, M., Clemente-Cesares, P., Jardi, R., Formiga-Cruz, M., Schaper, M., Valdes, A., RodriguezFrias, F., Esteban, R., Girones, R., 2004. Sporadic cases of acute autochthonous hepatitis E in Spain. J. Hepatol. 41,126-131. 
1 Buti, M., Dominguez, A., Plans, P., Jardi, R., Schaper, M., Espunes, J., Cardenosa, N., Rodriguez-

2 Frias, F., Esteban, R., Plasencia, A., Salleras, L., 2006. Community-based seroepidemiological survey of hepatitis E virus infection in Catalonia, Spain. Clin. Vaccine Immunol. 13, 1328-1332.

Caprioli, A., Martelli, F., Ostanello, F., Di Bartolo, I., Ruggeri, F.M., Del Chiaro, L., Tolari, F., 2007. Detection of hepatitis E virus in Italian pig herds. Vet. Rec. 161, 422-423.

Colson, P., Borentain, P., Queyriaux, B., Kaba, M., Moal, V., Gallian, P., Heyries, L., Raoult, D., Gerolami, R., 2010. Pig liver sausage as a source of hepatitis E virus transmission to humans. J. Infect. Dis. 202, 825-834.

Dalton, H.R., Thurairajah, P.H., Fellows, H.J., Hussaini, H.S., Mitchell, J., Bendall, R., Banks, M., Ijaz, S., Teo, C.G., Levine, D.F., 2007. Autochthonous hepatitis E in southwest England. J. Viral Hepat. 14, 304-309.

Dalton, H.R., Bendall, R., Ijaz, S., Banks, M., 2008. Hepatitis E: an emerging infection in developed countries. Lancet Infect. Dis. 8, 698-709.

de Deus, N., Seminati, C., Pina, S., Mateu, E., Martín, M., Segalés, J., 2007. Detection of hepatitis E virus in liver, mesenteric lymph node, serum, bile and feces of naturally infected pigs affected by different pathological conditions. Vet. Microbiol. 119, 105-114.

de Deus, N., Casas, M., Peralta, B., Nofrarías, M., Pina, S., Martín, M., Segalés, J., 2008. Hepatitis E virus infection dynamics and organic distribution in naturally infected pigs in a farrow-tofinish farm. Vet. Microbiol. 132, 19-28.

Di Bartolo, I., Martelli, F., Inglese, N., Pourshaban, M., Caprioli, A., Ostanello, F., Ruggeri, F.M., 2008. Widespread diffusion of genotype 3 hepatitis $\mathrm{E}$ virus among farming swine in Northern Italy. Vet. Microbiol. 132, 47-55.

Di Martino, B., Di Profio, F., Martella, V., Di Felice, E., Di Francesco, C.E., Ceci, C., Marsilio, F., 2010. Detection of hepatitis E virus in slaughtered pigs in Italy. Arch. Virol. 155, 103-106

Emerson, S.U., Purcell, R.H., 2003. Hepatitis E virus. Rev. Med. Virol. 13, 145-154. 
1 Emerson, S.U, Anderson D., Arankalle, V.A., Meng, X.J., Purdy, M., Schlauder, G.G. and Tsarev,

2

3

4

5 S.A., Hepevirus. In: C.M. Fauquet, M.A. Mayo, J. Maniloff, U. Desselberger and L.A. Ball, Editors, 2004. Virus Taxonomy, VIIIth Report of the ICTV, Elsevier/Academic Press, London 851-855.

Erker, J.C., Desai, S.M., Mushahwar, I.K., 1999. Rapid detection of Hepatitis E virus RNA by reverse transcription-polymerase chain reaction using universal oligonucleotide primers. J. Virol. Methods 81, 109-113.

Favorov, M.O., Kosoy, M.Y., Tsarev, S.A., Childs, J.E., Margolis, H.S., 2000. Prevalence of antibody to hepatitis E virus among rodents in the United States. J. Infect. Dis. 181, 449455.

Feagins, A.R., Opriessnig, T., Guenette, D.K., Halbur, P.G., Meng, X.J., 2007. Detection and characterization of infectious Hepatitis E virus from commercial pig livers sold in local grocery stores in the USA. J. Gen. Virol. 88, 912-917.

Fernandez-Barredo, S., Galiana, C., Garcia, A., Vega, S., Gomez, M.T., Perez-Gracia, M.T., 2006. Detection of hepatitis E virus shedding in feces of pigs at different stages of production using reverse transcription-polymerase chain reaction. J. Vet. Diagn. Invest. 18, 462-465.

Fogeda, M., Avellón, A., Cilla, C.G., Echevarría, J.M., 2009. Imported and autochthonous hepatitis E virus strains in Spain. J. Med. Virol. 81, 1743-1749.

Galiana, C., Fernández-Barredo, S., García, A., Gómez, M.T., Pérez-Gracia, M.T., 2008. Occupational exposure to hepatitis E virus (HEV) in swine workers. Am J. Trop. Med. Hyg. $78,1012-1015$.

Halbur, P.G., Kasorndorkbua, C., Gilbert, C., Guenette, D., Potters, M.B., Purcell, R.H., Emerson, S.U., Toth, T.E., Meng, X.J., 2001. Comparative pathogenesis of infection of pigs with hepatitis E viruses recovered from a pig and a human. J. Clin. Microbiol. 39, 918-923.

Huang, F.F., Haqshenas, G., Guenette, D.K., Halbur, P.G., Schommer, S.K., Pierson, F.W., Toth, T.E., Meng, X.J., 2002. Detection by reverse transcription-PCR and genetic characterization 
of field isolates of swine hepatitis E virus from pigs in different geographic regions of the United States. J. Clin. Microbiol. 40, 1326-1332.

Ijaz, S., Arnold, E., Banks, M., Bendall, R.P., Cramp, M.E., Cunningham, R., Dalton, H.R., Harrison, T.J., Hill, S.F., Macfarlane, L., Meigh, R.E., Shafi, S., Sheppard, M.J., Smithson, J., Wilson, M.P., Teo, C.G., 2005. Non-travel-associated hepatitis E in England and Wales: demographic, clinical, and molecular epidemiological characteristics. J. Infect. Dis. 192, 1166-1172.

Kaba, M., Davoust, B., Marié, J.L., Barthet, M., Henry, M., Tamalet, C., Raoult, D., Colson, P., 2009. Frequent transmission of hepatitis E virus among piglets in farms in Southern France. J. Med. Virol. 81, 1750-1759.

Kanai, Y., Tsujikawa, M., Yunoki, M., Nishiyama, S., Ikuta, K., Hagiwara, K., 2010. Long-term shedding of hepatitis E virus in the feces of pigs infected naturally, born to sows with and without maternal antibodies. J. Med. Virol. 82, 69-76.

Leblanc, D., Ward, P., Gagne, M.J., Poitras, E., Muller, P., Trottier, Y.L., Simard, C., Houde, A., 2007. Presence of hepatitis E virus in a naturally infected swine herd from nursery to slaughter. Int. J. Food Microbiol. 117, 160-166.

Li, T.C., Chijiwa, K., Sera, N., Ishibashi, T., Etoh, Y., Shinohara, Y., Kurata, Y., Ishida, M., Sakamoto, S., Takeda, N., Miyamura, T., 2005. Hepatitis E virus transmission from wild boar meat, Emerg. Infect. Dis. 11, 1958-1960.

Lu, L., Li, C., Hagedorn, C.H., 2006. Phylogenetic analysis of global hepatitis E virus sequences: genetic diversity, subtypes and zoonosis. Rev. Med. Virol. 16, 5-36.

Mansuy, J.M., Peron, J.M., Abravanel, F., Poirson, H., Dubois, M., Miedouge, M., Vischi, F., Alric, L., Vinel, J.P., Izopet, J., 2004. Hepatitis E in the south west of France in individuals who have never visited an endemic area. J. Med. Virol. 74, 419-424. 
1 Mansuy, J.M., Legrand-Abravanel, F., Calot, J.P., Peron, J.M., Alric, L., Agudo, S., Rech, H.,

2

Destruel, F., Izopet, J., 2008. High prevalence of anti-hepatitis E virus antibodies in blood donors from SouthWest France. J. Med. Virol. 80, 289-293.

Mansuy, J.M., Abravanel, F., Miedouge, M., Mengelle, C., Merviel, C., Dubois, M., Kamar, N., Rostaing, L., Alric, L., Moreau, J., Peron, J.M., Izopet, J., 2009. Acute hepatitis E in southwest France over a 5-year period. J. Clin. Virol. 44, 74-77.

Martelli, F., Caprioli, A., Zengarini, M., Marata, A., Fiegna, C., Di Bartolo, I., Ruggeri, F.M., Delogu, M., Ostanello, F., 2008. Detection of hepatitis E virus (HEV) in a demographic managed wild boar (Sus scrofa scrofa) population in Italy. Vet. Microbiol. 126, 74-81.

Martelli, F., Toma, S., Di Bartolo, I., Caprioli, A., Ruggeri, F.M., Lelli, D., Bonci, M., Ostanello, F., 2010. Detection of Hepatitis E Virus (HEV) in Italian pigs displaying different pathological lesions. Res. Vet. Sci. 88, 492-496.

Matsuda, H., Okada K., Takahashi K., Mishiro, S., 2003. Severe hepatitis E virus infection after ingestion of uncooked liver from a wild boar. J. Infect. Dis. 188, 944.

McCreary, C., Martelli, F., Grierson, S., Ostanello, F., Nevel, A., Banks, M., 2008. Excretion of hepatitis E virus by pigs of different ages and its presence in slurry stores in the United Kingdom. Vet. Rec. 163, 261-265.

Meng, X.J., Purcell, R.H., Halbur, P.G., Lehman, J.R., Webb, D.M., Tsareva, T.S., Haynes, J.S., Thacker, B.J.,. Emerson, S.U., 1997. A novel virus in swine is closely related to the human hepatitis E virus, Proc. Natl. Acad. Sci. U.S.A. 94, 9860-9865.

Meng, X.J., Wiseman, B., Elvinger, F., Guenette, D.K., Toth, T.E., Engle, R.E., Emerson, S.U., Purcell, R.H., 2002. Prevalence of antibodies to hepatitis E virus in veterinarians working with swine and in normal blood donors in the United States and other countries, J. Clin. Microbiol. 40, 117-122.

Mushawar, I.K., 2008. Hepatitis E virus: Molecular virology, clinical features, diagnosis, transmission, epidemiology and prevention. J. Med. Virol. 80, 646-658 
1 Norder, H., Sundqvist, L., Magnusson, L., Østergaard Breum, S., Löfdahl, M., Larsen, L.E.,

2

3

4 5 Hjulsager, C.K., Magnius, L., Böttiger, B.E., Widén, F., 2009. Endemic hepatitis E in two Nordic countries. Euro Surveill. 14, 14.

Panda, S.K., Thakral, D., Rehman, S., 2007. Hepatitis E virus. Rev. Med. Virol. 17, 151-180.

Peralta, B., Mateua E., Casasa, M., de Deusa, N., Martín, M., Pina, S., 2009. Genetic characterization of the complete coding regions of genotype 3 hepatitis E virus isolated from Spanish swine herds. Virus Res. 139, 111-116.

Péron, J.M., Mansuy, J.M., Poirson, H., Bureau, C., Dupuis, E., Alric, L., Izopet, J., Vinel, J.P., 2006. Hepatitis E is an autochthonous disease in industrialized countries. Analysis of 23 patients in South-West France over a 13-month period and comparison with hepatitis A. Gastroenterol. Clin. Biol. 30, 757-762.

Purcell, R.H., Emerson, S.U., 2001. Hepatitis E virus. In: D. Knipe, P. Howley, D. Griffin, R. Lamb, M. Martin and B. Roizman et al., Editors, Fields Virology (4th ed.), Lippincott: Williams and Wilkins, Philadelphia, 3051-3061.

Rose, N., Boutrouille, A., Fablet, C., Madec, F., Eloit, M., Pavio, N., 2010. The use of Bayesian methods for evaluating the performance of a virus-like particles-based ELISA for serology of hepatitis E virus infection in swine. J. Virol. Methods. 163, 329-335.

Rutjes, S.A., Lodder,W.J., Bouwknegt, M., de Roda Husman, A.M., 2007. Increased hepatitis E virus prevalence on Dutch pig farms from 33 to $55 \%$ by using appropriate internal quality controls for RT-PCR. J. Virol. Methods 143, 112-116.

Rutjes, S.A., Lodder ,W.J., Lodder-Verschoor, F., van den Berg, H.H., Vennema, H., Duizer, E., Koopmans, M., de Roda Husman, A.M., 2009. Sources of hepatitis E virus genotype 3 in The Netherlands. Emerg. Infect. Dis. 15, 381-387.

Schlauder, G.G., Mushahwar, I.K., 2001. Genetic heterogeneity of hepatitis E virus. J. Med. Virol. $65,282-292$. 
1 Seminati, C., Mateu, E., Peralta, B., de Deus, N., Martin, M., 2008. Distribution of hepatitis E virus

2 infection and its prevalence in pigs on commercial farms in Spain. Vet. J. 175, 130-132.

Tei, S., Kitajima, N., Takahashi, K., Mishiro, S., 2003. Zoonotic transmission of hepatitis E virus from deer to human beings, Lancet 362, 371-373.

Vasickova, P., Psikal, I., Widen, F., Smitalova, R., Bendova, J., Pavlik, I., Kralik, P., 2009. Detection and genetic characterization of Hepatitis E virus in Czech pig production herds. Res. Vet. Sci. 87, 143-148.

Vulcano, A., Angelucci, M., Candelora, E., Martini, V., Patti, A.M., Mancini, C., Santi, A.L., Calvari, A., Casagni, L., Lamberti, A., 2007. HEV prevalence in the general population and among workers at zoonotic risk in Latium Region. Ann. Ig. 19, 181-186.

Wang, Y.C., Zhang, H.Y., Xia, N.S., Peng, G., Lan, H.Y., Zhuang, H., Zhu, Y.H., Li, S.W., Tian, K.G., Gu, W.J., Lin, J.X., Wu, X., Li, H.M., Harrison, T.J., 2002. Prevalence, isolation, and partial sequence analysis of hepatitis E virus from domestic animals in China. J. Med. Virol. $67,516-521$.

Williams, T.P., Kasorndorkbua, C., Halbur, P.G., Haqshenas, G., Guenette, D.K., Toth, T.E., Meng, X.J., 2001. Evidence of extrahepatic sites of replication of the hepatitis E virus in a swine model. J. Clin. Microbiol. 39, 3040-46.

Yazaki, Y., Mizuo, H., Takahashi, M., Nishizawa, T., Sasaki, N., Gotanda, Y., Okamoto, H., 2003. Sporadic acute or fulminant hepatitis E in Hokkaido, Japan, may be food-borne, as suggested by the presence of hepatitis E virus in pig liver as food. J. Gen. Virol. 84, 23512357.

Zanetti, A.R., Schlauder, G.G., Romano, L., Tanzi, E., Fabris, P., Dawson, G.J., Mushahwar, I.K., 1999. Identification of a novel variant of hepatitis E virus in Italy. J. Med. Virol. 57, 356360. 
1 Zhao, C., Ma, Z., Harrison, T.J., Feng, R., Zhang, C., Qiao, Z., Fan, J., Ma, H., Li, M., Song, A.,

2

3

4
Wang, Y.A., 2009. Novel genotype of hepatitis E virus prevalent among farmed rabbits in China. J. Med. Virol. 81, 1371-1379.

4. 
Figure 1. Dendrogram, drawn using UPGMA and an avian HEV strain (United States, accession no. AY535004) as outgroup, was based on partial nucleotide sequence of the ORF2 fragment. GenBank accession no., origin, country, and genotype are reported for all strains; for strains identified in this study the sample origin is also indicated. Strains identified in this study are indicated with symbol and in boldface type. 
Table 1. Molecular detection of HEV in bile, feces and liver from swine, by age of individual

\begin{tabular}{|c|c|c|c|c|c|c|}
\hline \multirow{3}{*}{$\begin{array}{c}\text { Matrix } \\
\text { Bile, feces and liver }\end{array}$} & \multicolumn{6}{|c|}{ HEV positive/tested samples (\%) } \\
\hline & \multicolumn{2}{|c|}{$\begin{array}{c}\text { Young } \\
\text { (3-4 months) }\end{array}$} & \multicolumn{2}{|c|}{$\begin{array}{c}\text { Adult } \\
\text { (9-10 months) }\end{array}$} & \multicolumn{2}{|c|}{ Total } \\
\hline & $0 / 20$ & $(0.0)$ & $1 / 28$ & $(3.6)$ & $1 / 48$ & $(2.1)$ \\
\hline Bile and feces & $9 / 20$ & $(45.0)$ & $0 / 28$ & $(0.0)$ & $9 / 48$ & $(18.8)$ \\
\hline Bile and liver & $2 / 20$ & $(10.0)$ & $3 / 28$ & $(10.7)$ & $5 / 48$ & $(10.4)$ \\
\hline Feces and liver & $2 / 20$ & $(10.0)$ & $0 / 28$ & $(0.0)$ & $2 / 48$ & $(4.2)$ \\
\hline Bile only & $2 / 20$ & $(10.0)$ & $6 / 28$ & $(21.4)$ & $8 / 48$ & $(16.7)$ \\
\hline Feces only & $2 / 20$ & $(10.0)$ & $2 / 28$ & $(7.1)$ & $4 / 48$ & $(8.3)$ \\
\hline \multirow[t]{2}{*}{ Liver only } & $2 / 20$ & $(10.0)$ & $0 / 28$ & $(0.0)$ & $2 / 48$ & $(4.2)$ \\
\hline & \multicolumn{6}{|c|}{+2} \\
\hline Total bile $^{\mathrm{a}}$ & $13 / 19$ & $(68.4)$ & $10 / 26$ & $(38.5)$ & $23 / 45$ & (51.1) \\
\hline Total feces & $13 / 20$ & $(65.0)$ & $3 / 28$ & (10.7) & $16 / 48$ & $(33.3)$ \\
\hline Total liver & $6 / 20$ & $(30.0)$ & $4 / 28$ & $(14.3)$ & $10 / 48$ & (20.8) \\
\hline $\begin{array}{l}\text { Pigs positive in at least one } \\
\text { sample }\end{array}$ & $19 / 20$ & $(95.0)$ & $12 / 28$ & $(42.9)$ & $31 / 48$ & (64.6) \\
\hline $\begin{array}{l}\text { Pigs negative in any } \\
\text { samples }\end{array}$ & $1 / 20$ & $(5.0)$ & $16 / 28$ & $(57.1)$ & $17 / 48$ & (35.4) \\
\hline
\end{tabular}

${ }^{\mathrm{a}}$ For 3 of 48 animals, bile were not available 
Table 2. Molecular detection of HEV RNA in different samples from HEV seropositive and seronegative pigs.

\section{HEV RNA positive samples}

\begin{tabular}{lcccc}
\hline & Bile & Liver & Feces & \\
\hline & - & - & - & $\left(15^{\mathrm{a}}\right)$ \\
& + & - & - & $(7)$ \\
HEV Seropositive & + & + & - & $(3)$ \\
& + & + & + & $(1)$ \\
& + & - & + & $(8)$ \\
Total & - & - & + & $(3)$ \\
& - & + & + & $(1)$ \\
& - & + & - & $(2)$ \\
HEV Seronegative & $\mathbf{1 9}$ & $\mathbf{7}$ & $\mathbf{1 3}$ & $(40)$ \\
& - & - & - & $(2)$ \\
& + & - & - & $(2)$ \\
& + & + & - & $(0)$ \\
Total & + & + & + & $(0)$ \\
Grand total & + & - & + & $(1)$ \\
& - & - & + & $(0)$ \\
\hline a Figures & - & + & + & $(6)$ \\
\hline
\end{tabular}

${ }^{a}$ Figures in parentheses indicate the numbers of pigs exhibiting the pattern of HEV RNA positivity in the corresponding line.

${ }^{b}$ Figures in bold indicate the numbers of samples resulted positive for HEV RNA, by group of animals.

${ }^{c}$ Two pigs of the total 48 investigated in this study were not included, because their sera were unavailable for HEV antibody determination. 


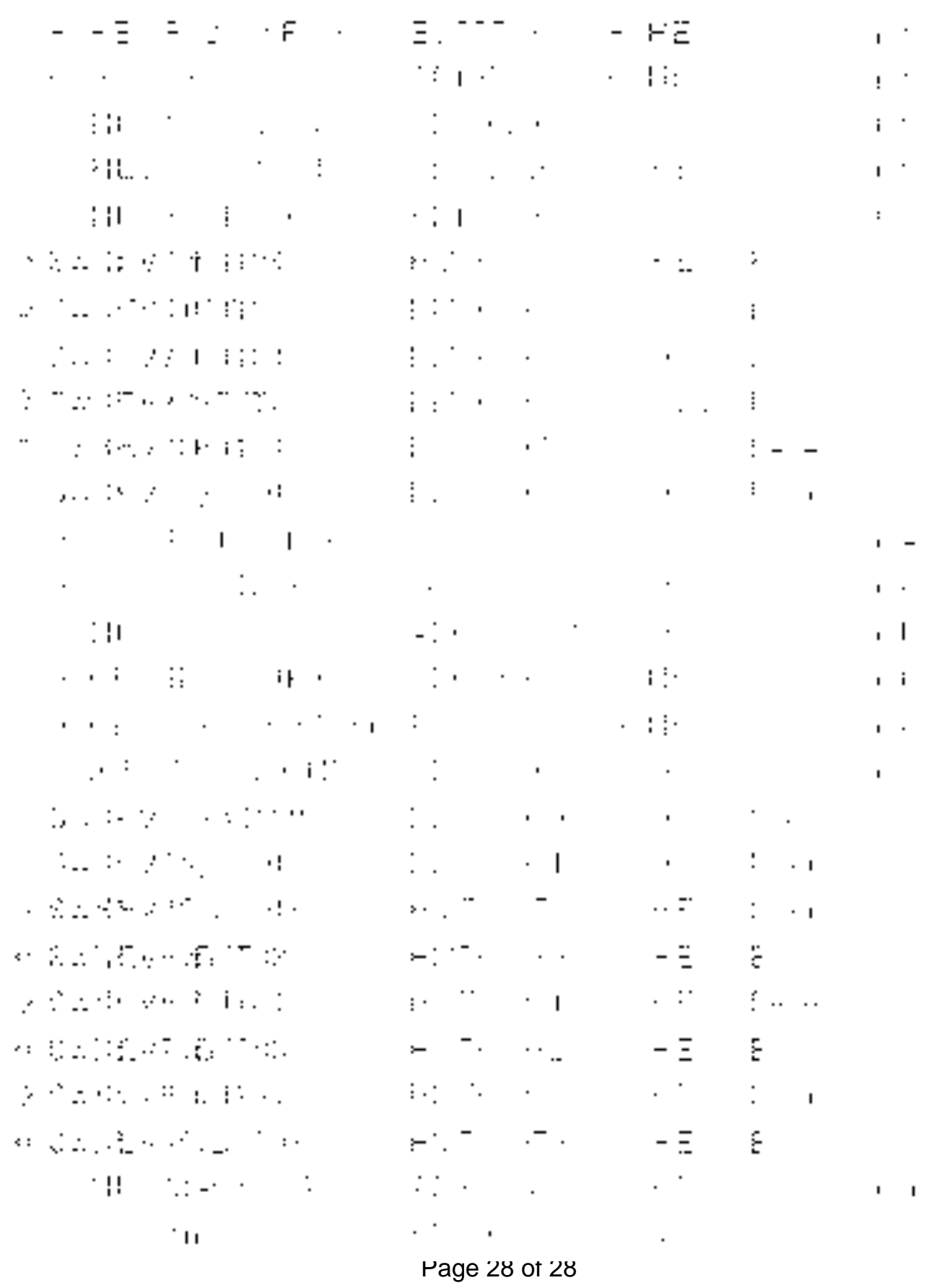

